\title{
Prevention of Postpartum Haemorrhage Using Carbetocin Versus Misoprostol in Patients with Severe Preeclampsia
}

\author{
Hossam eldeen Mostafa ${ }^{1, *}$ MSc., Mohamed khaled Mostafa ${ }^{2}$ PhD., Hasan Ahmed Abdrabou ${ }^{2}$ PhD., \\ Emad Mohamed Ibrahim Atallah ${ }^{2}$ MD.
}

\author{
* Corresponding Author: \\ Hossam eldeen Mostafa \\ hossammakbool9@gmail.com
}

Received for publication November 12, 2020; Accepted January 21, 2021; Published online January 21, 2021.

Copyright 2020 The Authors published by Al-Azhar University, Faculty of Medicine, Cairo, Egypt. All rights reserved. This an openaccess article distributed under the legal terms, where it is permissible to download and share the work provided it is properly cited. The work cannot be changed in any way or used commercially.

doi: $10.21608 /$ aimj.2021.49597.1350

${ }^{1}$ Obstetrics and Gynecology

Department, Sohag General Hospital, Egypt.

${ }^{2}$ Obstetrics and Gynecology

Department, Faculty of Medicine, Al-Azhar University Cairo, Egypt.

\section{ABSTRACT}

Background: A significant reason of maternal deaths is postpartum hemorrhage (PPH) that accounted for one-quarter of all maternal mortality globally. Primary postpartum hemorrhage (PPH) is conventionally described as a loss of blood of $\geq 500 \mathrm{ml}$ within the first 24 hours following childbirth.

Aim of the work: Using carbetocin versus misoprostol in postpartum hemorrhage prevention in sufferers with intense preeclampsia.

Patients and methods: A randomized prospective study is done to compare use carbetocin vs misoprostol in postpartum hemorrhage prevention with severe preeclampsia. In the present research a total of 100 patients who attended Sohag general Hospital included. First group was formed of 50 pregnant women candidate for cesarean section delivery with intense preeclampsia obtained carbetocin (IV injection (100 ug ,one ampoule pabal) following baby delivery. While the second group is formed of another 50 pregnant women that are also candidate for cesarean section delivery with intense preeclampsia but obtained Sublingual 600 ug misoprostol following baby delivery.

Results: The findings revealed that there was a highly substantial statistical variation among the baseline \& post-partum Hb \& HCT in both Misoprostol group and carbitocin group.

Conclusion: Carbetocin is more effective than Misoprostol in preventing incidence of atonic postpartum hemorrhage in patients performing elective caesarean delivery with severe preeclampsia.

Keywords: Postpartum Haemorrhage; Preeclampsi; Carbetocin; Misoprostol.

Disclosure: The authors have no financial interest to declare in relation to the content of this article. The Article Processing Charge was paid for by the authors.

Authorship: All authors have a substantial contribution to the article.

\section{INTRODUCTION}

A significant reason of maternal deaths is postpartum hemorrhage (PPH) that accounted for one-quarter of all maternal mortality globally. In the first 24 hours after childbirth, primary postpartum hemorrhage (PPH) is conventionally characterized as loss of blood of $\geq 500 \mathrm{ml}$. It accounted for around onequarter among all maternal mortality globally and this becomes a significant reason of maternal deaths. While maternal deaths in developed countries have become a rare occurrence, they remain a key indication of the standard of obstetric care and the health status of mothers. ${ }^{14}$

Uterine atony, pathological placenta such as placental abruption, lower genital laceration, retained placental tissue, vascular malformation, coagulopathy, and uterine rupture are the most common reasons of postpartum hemorrhage. Previous PPH, overweight, extended or augmented labor, more than one pregnancy, preceding caesarean section, polyhydramnios, and macrosomia encompass risk factors for PPH. However, most females with PPH have low- hazard being pregnant and no known hazard factors. Consequently, prevention of PPH in all women is important ${ }^{9}$.

In pregnancy, hypertensive disorders are correlated with substantial maternal mortality and morbidity. It is documented that women with high blood pressure disorder have a higher danger of growing postpartum hemorrhage (PPH) ${ }^{8}$.

Preeclampsia (PE) is a circumstance is caused in pregnant women by high blood pressure and proteinuria, whereas after the twentieth week of gestation, high blood pressure is described as a blood pressure equivalent to or greater than $140 / 90 \mathrm{mmHg}$, and proteinuria is described as either urinary excretion of higher than $300 \mathrm{mg}$ of protein in $24 \mathrm{hrs}$ or the existence of $3 \mathrm{mg} / \mathrm{dL}$ (almost $1+$ dipstick test) of protein in two random urine specimens ${ }^{6}$. 
The World Health Organization (WHO) reports that in low-resource environments, PE / E accounts for at least $16 \%$ of maternal mortality without the trained providers and facilities needed to prevent, diagnose and treat the disease ${ }^{3}$.

An oral analogue of prostaglandin E1, Misoprostol that may be given directly after birth provides a significant substitute to the prevention of PPH in low-resource and domestic births settings in which oxytocin is not accessible or in which its use is not possible ${ }^{\mathbf{1 1}}$.

Carbetocin is a synthetic analogue of long-acting oxytocin which may be supplied either intravenously or intramuscularly as an injection with a single dose. Carbetocin administered intravenously has a half-life of around 40 minutes, about 4-10 times longer than that of the oxytocin reported. Carbetocin achieves peak plasma levels in less than 30 minutes after intramuscular injection and has $80 \%$ bioavailability ${ }^{13}$.

\section{PATIENTS AND METHODS}

Study design:A randomized prospective study.

Subjects: A total of 100 patients attending to Sohag general Hospital will be included in the study. First group is formed of 50 pregnant women candidate for delivery of Cesarean section with excessive preeclampsia who will receive carbetocin after childbirth. While the second group is formed of another 50 pregnant women that are also candidate for Cesarean section delivery with severe preeclampsia but will receive misoprostol after birth of the baby.

Inclusion criteria: Pre-eclamptic women, Single embryo, Gestational period more than 28 weeks, Cesarean section delivery.

Exclusion criteria: HELLP syndrome, Eclampsia, Abruptio-placentae,

Polyhydramnios,

Chorioamnionitis, Multiple pregnancies.

Methods: All of the patients will be subjected to the following: Full history (demographic data and personal history, detailed history of general health condition and chronic or current diseases), Detailed obstetric and menstrual history, General and local examination including: Vital signs, Full pelvic examination., Abdominal ultrasonography.

Measurement of blood loss: A clean plastic lined absorbent drape put under woman's buttocks to collect all the blood lost after delivery of the baby and drainage of the amniotic fluid. The drape was changed as many times as needed. The woman stayed on the drape and wear a pad over the next 60 min, using usual guidelines for management of postpartum haemorrhage. All drapes and pads were weighed on an electronic scale, and the known dry weight of the linen was subtracted. As $1 \mathrm{ml}$ of blood weighs close to $1 \mathrm{~g}$, the balance in grams was assumed to be the total blood loss in $\mathrm{m}$
Ethical considerations: The study will be approved by sohag general hospital; An informed written consent will be taken from all of the participants in the study.

\section{Statistical analysis}

Using the Statistical Program for Social Science (SPSS) version 15.0, the data was analyzed. The mean \pm standard deviation (SD) was expressed as quantitative data. The frequency and percentage were expressed as qualitative data. $\mathrm{P}$-value $<0.05$ was deemed to be substantial, P-value $<0.001$ to be highly substantial and P-value $>0.05$ to be nonsubstantial.

RESULTS

\begin{tabular}{|c|c|c|c|c|}
\hline \multicolumn{2}{|c|}{ Baseline } & $\begin{array}{c}\text { Misoprostol } \\
\text { group } \\
\text { Variables }\end{array}$ & $\begin{array}{c}\text { Carbetocin } \\
\text { group } \\
(\mathbf{N = 5 0})\end{array}$ & $\begin{array}{c}\text { P- } \\
\text { value }\end{array}$ \\
\hline \multirow{2}{*}{ Hb(g/d) } & Mean & 10.72 & 10.87 & 0.360 \\
\cline { 2 - 4 } & \pm SD & 0.71 & 0.91 & NS \\
\hline \multirow{2}{*}{ HCT(\%) } & Mean & 36.45 & 36.02 & 0.081 \\
\cline { 2 - 4 } & \pm SD & 1.26 & 1.16 & NS \\
\hline \multirow{2}{*}{ PLT $(\mathbf{x 1 0} / \mathbf{c m m})$} & Mean & 275.28 & 266.74 & 0.411 \\
\cline { 2 - 4 } & \pm SD & 58.52 & 43.86 & NS \\
\hline
\end{tabular}

NS: p-value $>0.05$ is non-substantial.

Table 1: Comparison among studied groups as regard baseline $\mathrm{Hb}, \mathrm{HCT} \& \mathrm{PLT}$.

This table indicates no statistically substantial variation (p-value > 0.05) among the groups studied in regard to baseline $\mathrm{Hb}, \mathrm{HCT} \& \mathrm{PLT}$.

\begin{tabular}{|c|c|c|c|c|}
\hline \multicolumn{2}{|c|}{ Pariables } & $\begin{array}{c}\text { Misoprostol } \\
\text { group } \\
(\mathbf{N}=\mathbf{5 0})\end{array}$ & $\begin{array}{c}\text { Carbetocin } \\
\text { group } \\
(\mathbf{N}=\mathbf{5 0})\end{array}$ & $\begin{array}{c}\text { P- } \\
\text { value }\end{array}$ \\
\cline { 1 - 4 } $\begin{array}{c}\text { Hb } \\
(\mathbf{g} / \mathbf{d l})\end{array}$ & Mean & 9.75 & 10.19 & $\mathbf{0 . 0 0 6}$ \\
\cline { 2 - 4 } $\mathbf{H C T}$ & Mean & 0.66 & 0.86 & $\mathbf{S}$ \\
\cline { 2 - 4 }$(\boldsymbol{\%})$ & $\mathbf{\pm S D}$ & 14.75 & 34.97 & 0.366 \\
\end{tabular}

$\mathrm{S}: \mathrm{p}$-value $<0.05$ is substantial.

NS: p-value $>0.05$ is non-substantial.

Table 2: Comparison among studied groups as regard post-partum $\mathrm{Hb} \& \mathrm{HCT}$.

This table shows a statistically substantial variation (p-value < 0.05) among the groups studied in regard to postpartum $\mathrm{Hb}$. No statistically substantial variation (p-value > 0.05) among the groups studied in regard to post-partum HCT.

\begin{tabular}{|c|c|c|c|c|}
\hline \multicolumn{2}{|c|}{ Misoprostol } & $\begin{array}{c}\text { Baseline } \\
\text { Variables }\end{array}$ & $\begin{array}{c}\text { Post-partum } \\
(\mathbf{N}=\mathbf{5 0})\end{array}$ & \multirow{2}{*}{ P-value } \\
\hline \multirow{2}{*}{ Hb (g/dl) } & Mean & 10.72 & 9.75 & $<\begin{array}{c}\mathbf{0 . 0 0 1} \\
\text { HS }\end{array}$ \\
\cline { 2 - 4 } & \pm SD & 0.71 & 0.66 & $<\mathbf{0 . 0 0 1}$ \\
\multirow{2}{*}{ HCT $(\%)$} & Mean & 36.45 & 34.75 & HS \\
\cline { 2 - 4 } & $\mathbf{\pm S D}$ & 1.26 & 1.12 & \\
\hline
\end{tabular}

HS: p-value $<0.001$ is highly substantial.

Table 3: Comparison among baseline \&post-partum $\mathrm{Hb} \& \mathrm{HCT}$ in Misoprostol group.

This table indicates a highly statistically substantial variation ( $\mathrm{p}$-value $<0.001$ ) among the baseline \& post-partum Hb \& HCT in Misoprostol group. 


\begin{tabular}{|c|c|c|c|c|}
\hline \multicolumn{2}{|c|}{ Carbetocin } & $\begin{array}{c}\text { Baseline } \\
(\mathbf{N}=\mathbf{5 0})\end{array}$ & $\begin{array}{c}\text { Post-partum } \\
(\mathbf{N}=\mathbf{5 0})\end{array}$ & \multirow{2}{*}{ P-value } \\
\hline \multirow{2}{*}{ Hariables $(\mathrm{g} / \mathrm{dl})$} & Mean & 10.87 & 10.19 & $<\mathbf{0 . 0 0 1}$ \\
\cline { 2 - 4 } & \pm SD & 0.91 & 0.86 & HS \\
\hline \multirow{2}{*}{ HCT $(\%)$} & Mean & 36.02 & 34.97 & $<\mathbf{0 . 0 0 1}$ \\
\cline { 2 - 4 } & \pm SD & 1.16 & 1.32 & HS \\
\hline
\end{tabular}

HS: p-value $<0.001$ is highly substantial.

Table 4: Comparison among baseline \& post-partum $\mathrm{Hb} \& \mathrm{HCT}$ in Carbetocin group.

This table indicates a highly statistically substantial variation (p-value $<0.001$ ) among the baseline \& post-partum $\mathrm{Hb} \& \mathrm{HCT}$ in Carbetocin group.

\section{DISCUSSION}

Postpartum hemorrhage (PPH) in low-income countries is the main reason of maternal mortality and leads in almost $1 / 4$ of maternal mortality globally ${ }^{17}$. Through the use of prophylactic uterotonics during the third stage of labor and through well timed and suitable management, the majority of PPH deaths will be prevented ${ }^{17}$.

Postpartum hemorrhage ( $\mathrm{PPH})$ is described inside 24 hrs of delivery as a loss of blood of $\geq 500 \mathrm{~mL}$, whereas serious PPH (sPPH) is described within the same time frame as a loss of blood of $\geq 1,000 \mathrm{~mL}^{\mathbf{1 6}}$. Preeclampsia (PE) is a circumstance characterized in pregnant women by high blood pressure and proteinuria, whereas after the twentieth week of gestation, high blood pressure is described as a blood pressure equivalent to or greater than $140 / 90 \mathrm{mmHg}$, and proteinuria is described as either urinary excretion of more than $300 \mathrm{mg}$ of protein in $24 \mathrm{hrs}$ or the existence of $3 \mathrm{mg} / \mathrm{dL}(\geq 1+$ dipstick test $)$ of protein in two random urine specimens ${ }^{6}$.

The World Health Organization (WHO) reports that in low-resource environments, $\mathrm{PE} / \mathrm{E}$ accounts for at least $16 \%$ of maternal mortality without the trained providers and facilities needed to prevent, diagnose and treat the disease ${ }^{3}$. Carbetocin, commonly used after caesarean section to avoid PPH, is a more stable molecule and, when administered postpartum, causes a prolonged uterine response ${ }^{\mathbf{1 0}}$. A stable formulation (heat stable carbetocin, formerly referred to as carbetocin RTS) has been developed by a carbetocin manufacturer, making it a possible alternative for countries where it is problematic to maintain the cold chain ${ }^{15}$. Misoprostol is an analogue of prostaglandin (E1) with strong uterotonic properties and has been proposed as an alternative to uterotonic injectable agents to prevent PPH (9). It is inexpensive, heatstable and may be operated by many routes ${ }^{2}$.

Misoprostol has been widely recommended for postpartum hemorrhage prevention when other approaches are not available. Rectal route is the most common regimen reported for the treatment of postpartum hemorrhage ${ }^{7}$.

A Study found that in women with preeclampsia, the rate of severe postpartum bleeding $(>1500 \mathrm{ml})$ was two times higher than in women with normal blood pressure $(\mathrm{P}<0.005)$. In women with preeclampsia, postpartum bleeding $>500 \mathrm{ml}$ was also 1.6 times higher $(\mathrm{P}<0.005)$ than in women with normal blood pressure ${ }^{5}$. The aim of this study is to use carbetocin versus misoprostol for postpartum hemorrhage prevention with severe preclampsia.

The current study is a prospective randomized study. Included total of 100 patients attending Sohag general hospital classified into two groups: First group was formed of 50 pregnant women candidates for Caesarean section delivery with serious preeclampsia receiving carbetocin after baby delivery. While the second group was formed of another 50 pregnant women that are also candidate for Cesarean section delivery with severe preeclampsia but misoprostol was given after the baby was delivered. In the current research, the average age in the Misoprostol group was $27.4 \pm 3.6$ years, with a minimum age of 20 years and a maximum age of 34 years. As regard gravidity, there were 2 PG patients (4\%), 12 G2 patients (24\%), 22 G3 patients (44\%), $11 \mathrm{G} 4$ patients (22\%) and $1 \mathrm{G} 5$ patient (2\%). As regard parity, there were $14 \mathrm{P} 1$ patients $(28 \%), 15 \mathrm{P} 2$ patients $(30 \%), 7 \mathrm{P} 3$ patients (14\%), $2 \mathrm{P} 0+1$ patients (4\%), $1 \mathrm{P} 0+2$ patient (2\%), 5 $\mathrm{P} 1+1$ patients $(10 \%), 1 \mathrm{P} 1+2$ patient $(2 \%), 2 \mathrm{P} 2+1$ patient $(4 \%)$ and $1 \mathrm{P} 2+2$ patient $(2 \%)$. As regard previous deliveries, there were 2 patients (4\%) had NVD, 23 patients $(46 \%)$ had previous 1CS, 13 patients (26\%) had previous 2CS and 7 patients (14\%) had previous 3CS. As regard gestational age, the mean of GA in Misoprostol group was $37.02 \pm$ 1.22 weeks with minimum GA of 34 weeks and maximum GA of 39 weeks.

In the current research, the average age of the carbetocin group became $27.2 \pm 3.4$ years, with a minimum age of 20 years and a maximum age of 36 years, there were $14 \mathrm{G} 2$ patients (28\%), $21 \mathrm{G} 3$ patients $(42 \%), 13$ G4 patients (26\%), 1 G5 patient (2\%) and $1 \mathrm{G} 7$ patient (2\%). Also in the cabitocin group, there were $14 \mathrm{P} 1$ patients (28\%), $15 \mathrm{P} 2$ patients $(30 \%), 10 \mathrm{P} 3$ patients $(20 \%), 1 \mathrm{P} 6$ patient (2\%), $1 \mathrm{P} 0+1$ patient $(2 \%), 3 \mathrm{P} 0+2$ patients $(6 \%), 2$ $\mathrm{P} 1+1$ patients $(4 \%), 3 \mathrm{P} 2+1$ patients $(6 \%)$ and 1 $\mathrm{P} 3+1$ patient $(2 \%)$. As regard previous deliveries, there was 1 patient $(2 \%)$ had NVD, 18 patients $(36 \%)$ had previous $1 \mathrm{CS}, 21$ patients $(42 \%)$ had previous $2 \mathrm{CS}$ and 6 patients (12\%) had previous 3CS.

As regard gestational age, the mean of GA in carbetocin group was $36.92 \pm 1.12$ weeks with minimum GA of 34 weeks and maximum GA of 40 weeks. Prospective clinical research to compare the safety and effectiveness of carbetocin and misoprostol for the prevention of atonic postpartum hemorrhage in high-risk patients at the Department of Obstetrics and Gynecology, Aswan University Hospital. The patients' average age was 29.23 years. PG represents $(25 \%)$ of cases while the majority of cases were P1- P3 (52\%) and had no previous 
abortions (79\%). And the median gestational age was (37-38) weeks. In the present study no statistically substantial variations ( $\mathrm{p}$-value $>0.05$ ) among studied groups with respect to Blood pressure and pulse. In the present study there were no statistically substantial variations ( $p$-value $>0.05$ ) among studied groups with respect to serum ALB.

In the current study there were no statistically substantial variations ( $p$-value $>0.05$ ) among studied groups with respect to baseline $\mathrm{Hb}, \mathrm{HCT} \& \mathrm{PLT}$. As shown in table no. This go with the data of the study, there were no substantial variations among the two groups with respect to mean hemoglobin level before treatment. In a randomized managed trial performed by Nirmala et al 13, 1200 vaginally delivered women at high threat of PPH were studied to start comparing carbetocin $100 \mathrm{mg}$ IM to syntometrine IM. In the carbetocin group, researchers did find a substantial reduction in average blood loss as well as a substantial reduce in hemoglobin loss. In the current research there was a statistically substantial variation (p-value < 0.05) among the groups studied as regard post-partum $\mathrm{Hb}$. As shown in table no, these results go with that of study done by Mohamed et al. ${ }^{12}$

Comparing carbetocin and misoprostol reported that the amount of hemoglobin in women who acquired misoprostol decreased substantially compared to those who acquired carbetocin in women who have undergone cesarean section. In contrast to the research findings done at Aswan university mentioned above, there was no substantial variation among the two groups as regard mean haemoglobin level before and 24 hours after treatment. In the current research there is no statistically substantial variance ( $p$-value $>0.05$ ) among studied groups with respect to post-partum HCT. In a study done by Ali et $a l .{ }^{1}$, that was performed to evaluate the efficacy of Carbetocin relative to Oxytocinin in the avoidance of atonic post-partum hemorrhage in high-danger sufferers experiencing optional caesarean section and misoprodtol, hematocrit value assessment preoperative and 48 hours postoperatively after elective cesarean delivery had a mildly substantial disparity among the three groups studied $(\mathrm{p}<0.05)$

In contrary to study done by Elgazayerli ${ }^{4}$ which was carried out to assess the efficacy and side negative impacts of carbetocin, misoprostol and syntocinon in PPH prevention in sufferers having undergone optional caesarean delivery, showed a substantial reduction in intra and post-operative blood loss in the carbetocin group. Also, the decrease in both $\mathrm{Hb}$ and Hct level was significantly lower than the other two drugs. In the current research there is a highly substantial statistical variance (p-value $<0.001$ ) among baseline \& post-partum $\mathrm{Hb}$ \& HCT in Misoprostol group as shown in table no... .And also, there is a highly substantial statistical variance (p-value < 0.001) among baseline \& post-partum $\mathrm{Hb}$ \& HCT in Carbetocin group as shown in table no. 4 However in study done at obstetrics and gynecology,
Aswan university, the misoprostol group showing the higher drop in $\mathrm{Hb}(9.26 \pm 0.87)$ compared to carbetocin group $(9.95 \pm 1.02)$.

However In a study done by Ali et al ${ }^{\mathbf{1}}$, hemoglobin level delivery had a mildly substantial variance between the groups studied ( $p<0.05)$ The comparison of carbetocin and misoprostol without the inclusion as a comparator of the combination of misoprostol + oxytocin, not the comparison of the need for blood transfusion, of the additional uterotonic agents needed among the two groups was one drawback of the current research.

\section{CONCLUSION}

Carbetocin is more efficient than Misoprostol in preventing incidence of atonic postpartum hemorrhage in patients performing elective caesarean delivery with severe preeclampsia.

\section{REFERENCES}

1. Ali AA, Ahmed Ali MN, Hazem HA, et al. Carbetocin versus Oxytocin and Misoprostol in prevention of atonic post-partum hemorrhage in high risk patients planed for cesarean delivery, Int J Reprod Contracept Obstet Gynecol. 2018; 7(1):10-4.

2. Conde-Agudelo A, Nieto A, Rosas-Bermudez A et al. Misoprostol to reduce intraoperative and postoperative hemorrhage during cesarean delivery: a systematic review and meta-analysis. Am J Obstet Gynecol. 2013; 209(1): 1-40.

3. Cunningham FG, Leveno KJ, Bloom $\mathrm{S}$, et al. "Pregnancy hypertension." Williams obstetrics. 2010; 23: 706.

4. Elgazayerli WS. Comparison between syntocinon, misoprostol and carbetocin in reducing blood loss in elective caesarean section.

\section{DOI. 2019; 10.21608/ ebwhj.2019.45492}

5. Eskild A and Vatten LJ. Abnormal bleeding associated with preeclampsia: a population study of 315,085 pregnancies. ActaObstetGynecol Scand. 2009;88:154-8.

6. Fullerton G, Danielian P and Bhattacharya S. "Outcomes of pregnancy following postpartum haemorrhage." BJOG: An International Journal of Obstetrics \& Gynaecology .2013; 120(5): 621-7.

7. Ismail AMI, Mohamed Salah EDF and Hany AF. The Carbetocin Versus Misoprostol in Prevention of Postpartum Hemorrhage in High Risk Patients, Egyptian Journal of Hospital Medicine .2019; 77 (2): 4913-9. 
Mostafa et al - Prevention of postpartum haemorrhage using Carbetocin versus Misoprostol in patients with severe preeclampsia

8. Koopmans CM, Tuuk $\mathrm{K}$, Groen $\mathrm{H}$, et al. "Prediction of postpartum hemorrhage in women with gestational hypertension or mild preeclampsia at term." Acta obstetricia et gynecologica Scandinavica .2014;93(4): 399407.

9. Kramer M, Berg C, Abenhaim $\mathrm{H}$, et al. "Incidence, risk factors, and temporal trends in severe postpartum hemorrhage." Obstetric Anesthesia Digest .2014; 34(4): 201-2.

10. Malm M, Madsen I and Kjellström J Development and stability of a heat-stable formulation of carbetocin for the prevention of postpartum haemorrhage for use in low and middle-income countries .2018; $J \quad P e p$ Sci.:e3082.

11. Mobeen N, Durocher J, Zuberi N, et al "Administration of misoprostol by trained traditional birth attendants to prevent postpartum haemorrhage in homebirths in Pakistan: a randomised placebo-controlled trial." BJOG: An International Journal of Obstetrics \& Gynaecology. 2011; 118(3): 35361.

12. Mohamed AAA, Ahmed I, Parvin A et al. The effect of carbetocin compared to misoprostol in management of the third stage of labor and prevention of postpartum hemorrhage: a systematic review. International Journal of Gynecology. 2018; 16: 35-42.
13. Nirmala K, Zainuddin AA, Ghani NAA, et al."Carbetocin versus syntometrine in prevention of post-partum hemorrhage following vaginal delivery." Journal of Obstetrics and Gynaecology Research .2009; 35(1): 48-54

14. Sentilhes L, Lasocki S, Ducloy-Bouthors A, et al. "Tranexamic acid for the prevention and treatment of postpartum haemorrhage." British Journal of Anaesthesia. 2015;114(4): 576-87.

15. Theunissen FJ, Chinery L and Pujar YV. Current research on carbetocin and implications for prevention of postpartum haemorrhage. Reprod Health. 2018; 15: 94.

16. WHO. Recommendations for the prevention and treatment of postpartum haemorrhage. Geneva, Switzerland: World Health Organization.2012.

17. Widmer M, Piaggio G, Abdel-Aleem H, et al. Room temperature stable carbetocin for the prevention of postpartum haemorrhage during the third stage of labour in women delivering vaginally: study protocol for a randomized controlled trial. Trials. 2016;17: 143. 